\title{
Analisis Kemampuan Menyelesaikan Soal Cerita Matematika Ditinjau dari Kemampuan Verbal pada Siswa Kelas VII SMP Muhammadiyah Se-Kota Makassar
}

\author{
Wahyuddin ${ }^{1}$, Muhammad Ihsan ${ }^{2}$ \\ ${ }^{1}$ Dosen Pendidikan Matematika Universitas Mubammadivah Makassar \\ ${ }^{2}$ Dosen Pendidikan Matematika IAIN Palopo \\ Email : ${ }^{1}$ wahyu@unismuh.ac.id \\ 2 ihsan@iainpalopo.ac.id
}

\begin{abstract}
ABSTRAK. Penelitian ini bertujuan untuk mengetahui tingkat kemampuan kemampuan verbal dan kemampuan menyelesaikan soal cerita serta untuk mengetahui pengaruh kemampuan kemampuan verbal terhadap kemampuan menyelesaikan soal cerita matematika pada siswa kelas VII SMP Muhammadiyah Se-Kota Makassar. Jenis penelitian ini adalah ex-post facto yang bersifat kausalitas. Populasi penelitian ini adalah seluruh siswa kelas VII SMP Muhammadiyah Se-Kota Makassar sebanyak 1048 siswa yang tersebar di dalam 10 sekolah dan jumlah sampel sebanyak 145 siswa dengan teknik pengambilan sampel yaitu stratified cluster random sampling. Instrumen yang digunakan dalam penelitian ini adalah tes masing-masing variable dengan teknik analisis data yang digunakan adalah statistika deskriptif dan analisis infrensial (Analisis Correlation dan Analisis Regression). Hasil penelitian ini menunjukkan bahwa: (1) Tingkat kemampuan verbal siswa berada pada kategori sedang dengan nilai rata-rata 51,83; (2) Tingkat kemampuan menyelesaikan soal cerita siswa berada pada kategori sedang dengan nilai rata-rata 70,62; (3) Kemampuan verbal memiliki korelasi/hubungan dengan kemampuan menyelesaikan soal cerita matematika dengan besar hubungan $67,5 \%$; (3) Kemampuan verbal berpengaruh positif terhadap kemampuan menyelesaikan soal cerita dengan pengaruh sebesar $42 \%$ sedangkan sisanya sebesar 58\% dipengaruhi oleh variabel lain di luar model. Kemampuan verbal berpengaruh positif terhadap kemampuan menyelesaikan soal cerita siswa, hal tersebut dapat diartikan bahwa semakin baik atau semakin tinggi kemampuan verbal yang dimiliki oleh siswa maka kemampuan menyelesaikan soal cerita siswa tersebut akan semakin baik atau semakin tinggi.
\end{abstract}

Kata kunci: Kemampuan Verbal dan Kemampuan Menyelesaikan Soal Cerita Matematika.

\section{PENDAHULUAN}

Tujuan pembelajaran matematika yaitu; memahami konsep matematik, menggunakan penalaran, memecahkan masalah, mengomunikasikan gagasan dengan simbol, tabel, diagram, atau media lain untuk memperjelas keadaan atau masalah, dan memiliki sikap menghargai kegunaan matematika dalam kehidupan Wardani (2008; 9).

Salah satu tolak ukur keberhasilan siswa adalah dengan melihat hasil belajar siswa tersebut, hal ini juga berlaku pada mata pelajaran matematika. Dalam pelajaran matematika untuk memperoleh hasil belajar yang baik dipengaruhi oleh beberapa faktor, baik faktor dari dalam maupun faktor dari luar diri siswa tersebut. Salah satu faktor yang harus dipenuhi siswa untuk mendapatkan kemampuan dan hasil belajar matematika yang baik, maka siswa tersebut harus memiliki kemampuan berfikir verbal.

Soal cerita matematika merupakan salah satu bentuk soal matematika yang memuat aspek kemampuan untuk membaca, menalar, menganalisis serta mencari solusi, untuk itu siswa dituntut dapat menguasai kemampuan-kemampuan dalam menyelesaikan soal cerita matematika tersebut. Kemampuan membaca digunakan untuk menerjemahkan masalah, sedangkan menalar untuk 
mengetahui maksud permasalahan yang diberikan, kemudian kemampuan menganalisis langkahlangkah penyelesaian serta menerapkan konsep-konsep matematika dalam menyelesaikan permasalahan.

Soal cerita matematika sangat berperan dalam kehidupan sehari-hari siswa, karena soal tersebut mengedepankan permasalahan-permasalahan real yang sesuai dengan kehidupan seharihari, namun banyak guru yang mengeluh karena rendahnya kemampuan siswa dalam mengerjakan soal cerita. Hal ini terlihat dari banyaknya kesalahan siswa dalam mengerjakan soal-soal cerita sehingga prestasi matematika siswa rendah. Salah satu penyebab siswa tidak mampu mengerjakan soal cerita adalah mereka belum mengerti apa yang diketahui dan apa yang ditanyakan dalam soal cerita tersebut. Kesulitan siswa dalam menentukan suatu penyelesaian bukanlah diakibatkan karena siswa tidak menguasai langkah-langkah dalam menyelesaikan suatu soal cerita namun lebih cenderung kepada kesulitan siswa untuk memaknai soal tersebut, tanda operasi yang harus mereka gunakan dalam menyelesaikan soal-soal cerita tersebut.

Rendahnya kemampuan penalaran matematis siswa masih terlihat disaat mereka diberikan soal latihan dalam bentuk verbal atau dalam bentuk masalah nyata, hanya sebagian kecil siswa yang langsung mengerjakannya sementara sebagian lainnya hanya menunggu jawaban dari teman atau penjelasan guru kemudian menyalinnya, kurangnya keterampilan dan keaktifan siswa dalam proses pembelajaran terutama dalam menyelesaiakan soal/masalah matematika, dan rendahnya kemampuan siswa dalam pemecahan masalah matematika. Hal ini disebabkan berbagai faktor seperti siswa kurang menguasai perhitungan dan penalaran matematis, siswa mengalami kesulitan dalam menyelesaikan soal yang ditandai dengan banyaknya kesalahan-kesalahan yang dilakukan siswa dalam menjawab atau mengerjakan soal-soal. Siswa masih malu dalam mengomunikasikan gagasannya dan masih ragu-ragu dalam mengemukakan permasalahannya ketika siswa tersebut menghadapi suatu masalah dalam memecahkan persoalan matematika. Ketika ada masalah yang disajikan dalam bentuk lain (tidak sesuai dengan contoh yang diberikan) siswa masih bingung bagaimana menyelesaikannya. Hal ini mencerminkan penalaran siswa dalam proses pembelajaran relatif rendah, siswa belum mampu menyampaikan atau mengomunikasikan ide atau pendapatnya. Pendapat yang disampaikan oleh siswa sering kurang terstruktur sehingga sulit dipahami oleh guru maupun temannya.

Salah satu kemampuan yang erat kaitannya dengan hasil belajar siswa adalah adalah kemampuan verbal. Kemampuan verbal merupakan kemampuan berpikir dari seseorang dalam menuangkan suatu ide atau pendapat kepada orang atau pihak lain secara sistematis, efektif dan efisien serta mudah dipahami baik secara lisan maupun tulisan. Kemampuan verbal tidak hanya menuangkan ide atau pendapat yang ada di dalam pikiran saja, namun sebaliknya juga dapat menanggapi hal-hal yang bersifat verbal dari orang atau pihak lain.

Kemampuan verbal merupakan kemampuan untuk menyusun pikiran dengan jelas dan mampu menggunakan kemampuan ini secara kompeten melalui kata-kata untuk mengungkapkan pikiran-pikiran ini dalam berbicara, membaca dan menulis. Azwar (dalam Burhanuddin, 2012: 53) mengatakan bahwa kemampuan verbal yaitu kemampuan untuk memahami hubungan/makna kata, kosakata, dan penguasaan komunikasi lisan lebih lanjut kemampuan verbal adalah kemampuan untuk menyusun pikiran dengan jelas dan mampu menggunakan kemampuan ini secara kompeten melalui kata-kata untuk mengungkapkan pikiran-pikiran ini dalam berbicara, membaca dan menulis serta kemampuan membentuk ide-ide atau gagasan baru, serta mengkombinasikan ide-ide tersebut kedalam sesuatu yang baru berdasarkan informasi atau unsurunsur yang sudah ada, yang mencerminkan kelancaran, kelenturan, orisinalitas dalamberpikir divergen yang terungkap secara verbal.

Faktor lain yang harus dipenuhi siswa untuk mendapatkan kemampuan dan hasil belajar matematika yang baik adalah dengan kemampuan menyelesaikan soal. Kemampuan menyelesaikan soal merupakan kemampuan yang dimiliki siswa untuk menyelesaikan soal-soal matematika yang meliputi: (1) kemampuan menuliskan aspek yang diketahui, (2) kemampuan 
menuliskan aspek yang ditanyakan, (3) kemampuan membuat model matematika, (4) kemampuan menyelesaikan model matematika, dan (4) kemampuan menjawab pertanyaan soal.

\section{METODE PENELITIAN}

Penelitian ini termasuk penelitian ex-post fakto yang bersifat korelasional. Disebut ex - post fakto karena faktor yang dikumpulkan sudah ada sebelumnya, dan bersifat korelasional, karena diselidiki hubungan antara variabel. Variabel dalam penelitian ini terdiri dari variabel kemampuan verbal dan variabel dan kemampuan menyelesaikan soal cerita. Populasi dalam penelitian ini adalah seluruh siswa kelas VII SMP Muhammadiyah se-Kota Makassar yang terakreditasi A dan terakreditasi B yang tersebar dalam 10 sekolah. Teknik pengambilan sampel yang digunakan dalam penelitian ini adalah dengan menggunakan stratified cluster proporsional random sampling dimana sampel diambil adalah 50\% dari sekolah yang terakreditasi A atau sebanyak satu sekolah dan 50\% dari sekolah yang terakreditasi B atau sebanyak empat sekolah yaitu lima sekolah secara keseluruhan dimana tiap sekolah diambil satu kelas dengan jumlah sampel sebanyak 145 Siswa.

Dalam upaya mengumpulkan data yang akurat mengenai variabel-variabel yang dikaji, maka dalam penelitian ini menggnakan teknik yaitu: Tes sebagai instrumen pengumpul data adalah serangkaian pertanyaan yang digunakan untuk mengukur hasil kemampuan verbal dan kemampuan menyelesaikan soal cerita pada siswa kelas VII SMP Muhammadiyah Se-Kota Makassar.

Untuk memperoleh instrumen penelitian yang benar-benar memenuhi validitas dan reliabilitas atau dapat diandalkan dalam mengungkap data penelitian, maka ketiga alat tersebut disusun dengan langkah-langkah sebagai berikut: Membuat kisi-kisi tes, berdasarkan kisi-kisi tersebut, langkah selanjutnya adalah menyusun pernyataan untuk skala dan soal tes, sebelum digunakan, instrumen-instrumen tersebut terlebih dahulu divalidasi oleh validator dengan validitas isi (content validity), yaitu ketepatan suatu istrumen ditinjau dari segi materi yang diujikan (untuk tes), selanjunya dilakukan uji validitas item dan reliabilitas tes, dan pengujian hipotesis dan pembahasan.

Selanjutnya hasil penelitian dari masing-masing variabel diiterpretasikan dalam kateogiri Pedoman Interpretasi Variabel Penelitian Wayan Nurkancana, 1983: 114 sebagai berikut.

\begin{tabular}{cc} 
Tabel 1 Pedoman Interpretasi V ariabel Penelitian \\
Interval & Kategori \\
\hline $0-30$ & Sangat Rendah \\
$31-54$ & Rendah \\
$55-74$ & Sedang \\
$75-89$ & Tinggi \\
$90-100$ & Sangat Tinggi \\
\hline
\end{tabular}

\section{HASIL PENELITIAN DAN PEMBAHASAN}

Berdasarkan hasil penelitian diperoleh rata-rata skor kemampuan verbal dari 145 responden sebesar 15,55 berarti sebesar 51,83\% yang berada pada kategori sedang dengan pengklasifikasian kategori yaitu 1 atau 0,69\% berada pada kategori sangat rendah, 43 atau 26,66\% berada pada kategori rendah,84 atau 57,93\% berada pada kategori sangat sedang, 16 atau 11,03\% berada pada kategori tinggi, dan 1 atau $0.69 \%$ berada pada kategori sangat tinggi.

Skor kemampuan menyelesaikan soal cerita sebesar 70,62 dimana variable tersebut berada pada kategori sedang dengan pengklasifikasian kategori yaitu 2 atau 1,38\% berada pada kategori sangat rendah, 15 atau 10,35\% berada pada kategori rendah, 72 atau 49,66\% berada pada kategori 
sedang, 51 atau 35,17\% berada pada kategori tinggi, dan 4 atau 3,44\% berada pada kategori sangat tinggi.

Selanjutnya hasil analisis korelasi diperoleh nilai Pearson Correlation sebesar 0,675 dengan nilai sig. $=0.007<0.05$ hal tersebut diartikan bahwa kemampuan verbal memiliki korelasi/hubungan dengan kemampuan menyelesaikan soal cerita matematika dengan besar hubungan $67,5 \%$ dimana hal tersebut berada pada kategori sedang. Selanjutnya hasil analisis regresi diperoleh nilai $\mathrm{R}=0.665, \mathrm{R}$ Square $=0.442$, Adjusted $\mathrm{R}$ Square 0.420 , nilai $\mathrm{F}=23,99$ dengan sig. $=0.007$. hal tersebut dapat diiterpretasikan bahwa nilai $\mathrm{R}=0.665$, $\mathrm{R}$ Square $=0.442$, Adjusted $\mathrm{R}$ Square 0.420 , nilai $\mathrm{F}=23,99$ dengan sig. $=0.007$ menunjukkan bahwa hubungan antara variabel bebas dengan variabel terikat cukup besar yaitu sebesar 44,2\% dengan besar pengaruh variabel kemampuan verbal terhadap kemampuan menyelesaikan soal cerita sebesar $42 \%$ sedangkan sisanya sebesar 58\% dipengaruhi oleh variabel lain di luar model.

Kemampuan verbal siswa yang merupakan kemampuan siswa untuk memahami hubungan kata, kosa kata, dan menerima dengan cepat kata-kata tertentu berdasarkan informasi atau unsurunsur yang sudah ada. Di dalamnya juga termasuk kemampuan mengingat kata-kata dan pola yang membentuknya dengan indikator yaitu : sinonim, antonim, padanan kata, dan hubungan kata memiliki sebesar 51,83\% dimana hal tersebut berada pada kategori sedang.

Skor kemampuan menyelesaikan soal cerita sebesar 70,62 dimana hal tersebut berada pada kategori sedang. Sehingga kemampuan siswa dalam menyelesaikan soal cerita matematika dengan indicator yaitu (1) kemampuan menuliskan aspek yang diketahui, (2) kemampuan menuliskan aspek yang ditanyakan, (3) kemampuan menyelesaikan model matematika, dan (4) kemampuan menarik kesimpulan berada pada kategori sedang.

Selanjutnya dari hasil analisis korelasi diperoleh nilai Pearson Correlation sebesar 0,675 dengan nilai sig. $=0.007<0.05$ hal tersebut diartikan bahwa kemampuan verbal memiliki korelasi/hubungan dengan kemampuan menyelesaikan soal cerita matematika dengan besar hubungan $67,5 \%$ dimana hal tersebut berada pada kategori sedang. Lebih lanjut hasil analisis deskriptif dapat dijelaskan bahwa dari 145 siswa terdapat 40 atau 27,59\% siswa yang berada pada kategori tetap yaitu jika kemampuan verbal yang dimiliki berada pada kategori sedang, tinggi, atau sangat tinggi, maka kemampuan menyelesaikan soal cerita yang dimiliki juga berada pada kategori yang sama dengan kemampuan verbalnya; 98 atau 67,59\% siswa yang berada pada kategori meningkat yaitu jika kemampuan verbal yang dimiliki berada pada suatu kategori tertentu, maka kemampuan menyelesaikan soal cerita yang dimilikinya setingkat lebih tinggi dari kemampuan verbalnya; dan 7 atau 4,83\% siswa yang berada pada kategori menurun artinya kemampuan menyelesaikan soal cerita yang dimilikinya akan lebih rendah dari kemapuan verbalnya.

Lebih lanjut kemampuan verbal berpengaruh positif terhadap kemampuan menyelesaikan soal cerita dengan pengaruh sebesar 42\% sedangkan sisanya sebesar 58\% dipengaruhi oleh variabel lain di luar model. Kemampuan verbal berpengaruh positif terhadap kemampuan menyelesaikan soal cerita siswa, hal tersebut dapat diartikan bahwa semakin baik atau semakin tinggi kemampuan verbal yang dimiliki oleh siswa maka kemampuan menyelesaikan soal cerita siswa tersebut akan semakin baik atau semakin tinggi.

Siswa yang memiliki kemampuan untuk memahami hubungan kata, kosa kata, dan menerima dengan cepat kata-kata tertentu berdasarkan informasi atau unsur-unsur yang sudah ada, kemampuan mengingat kata-kata dan pola yang membentuknya, siswa yang memiliki banyak pengetahuan tentang perbendaharaan kata, memahami persamaan kata (sinonim), memahami lawan kata (antonim), padanan kata, dan hubungan kata, maka maka siswa tersebut akan lebih mudah untuk memanipulasi matematika, mengajukan dugaan, mengembangkan gagasan secara lisan, menarik kesimpulan, dan evaluasi.

Kemampuan verbal merupakan kemampuan untuk menyusun pikiran dengan jelas dan mampu menggunakan kemampuan ini secara kompeten melalui kata-kata untuk mengungkapkan pikiran-pikiran ini dalam berbicara, membaca dan menulis. Azwar (dalam Burhanuddin, 2012: 53) mengatakan bahwa kemampuan verbal yaitu kemampuan untuk memahami hubungan/makna 
kata, kosakata, dan penguasaan komunikasi lisan lebih lanjut kemampuan verbal adalah kemampuan untuk menyusun pikiran dengan jelas dan mampu menggunakan kemampuan ini secara kompeten melalui kata-kata untuk mengungkapkan pikiran-pikiran ini dalam berbicara, membaca dan menulis. Menurut (Soeharno 1984: 38) kemampuan verbal penting sekali dalam kegiatan pengajaran dan menentukan keberhasilan seseorang dalam belajar, sebab dengan kemampuan verbal yang tinggi, seseorang dapat mengerti ide serta konsep dan juga dapat dengan mudah berpikir dan memecahkan masalah yang dinyatakan dalam bentuk kata-kata. Berdasarkan kedua pendapat di atas terlihat begitu eratnya hubungan antara berpikir dan bahasa.

Berpikir dan bahasa memiliki hubungan erat, karena bahasa berhubungan dengan kemampuan verbal, maka kemampuan verbal pun memiliki hubungan dengan berpikir. Berpikir merupakan suatu aktifitas dalam belajar, sehingga kemampuan verbal pun berhubungan dengan belajar. Pernyataan tersebut didukung oleh pendapat Soeharno. Menurut (Soeharno 1984: 38) kemampuan verbal penting sekali dalam kegiatan pengajaran dan menentukan keberhasilan seseorang dalam belajar, sebab dengan kemampuan verbal yang tinggi, seseorang dapat mengerti ide serta konsep dan juga dapat dengan mudah berpikir dan memecahkan masalah yang dinyatakan dalam bentuk kata-kata.

Hasil penelitian ini sejalan dengan hasil penelitian Baharuddin (2012). Dengan hasil penelitian menunjukkan bahwa rata-rata hasil belajar siswa dengan kecenderungan tingkat kemampuan verbal tinggi secara keseluruhan baik yang diajar dengan strategi pembelajaran kooperatif TGT dan strategi pembelajaran kooperatif pendekatan struktural lebih tinggi dibandingkan dengan rata-rata hasil belajar siswa dengan kecenderungan tingkat kemampuan verbal rendah.

Hasil penelitian yang serupa dilakukan oleh Wasisto (2010) dengan hasil penelitian menjelaskan bahwa danya pengaruh yang positif dan signifikan antara kemampuan penalaran, kemampuan verbal dan kemampuan numerik terhadap kemampuan menyelesaikan soal cerita matematika pokok bahasan aritmetika social. Dan Efendi (2004) dengan hasil penelitian bahwa Kemampuan verbal merupakan salah satu faktor inteligensi yang juga menjadi salah satu faktor penentu keberhasilan siswa dalam berprestasi, terutama kemampuan memahami dan memberikan informasi dengan unsur kemampuan verbal yang sangat membantu dalam memahami lambing tulis, lisan, dan gerak berupa kecepatan, kode, operasi verbal. Sementara, usaha untuk mencapai prestasi belajar, tidak terlepas dari ketiga unsure tersebut. Lebih lanjut bahwa ada dua komponen kemampuan verbal ialah (a) pemahaman verbal dan (b) perbendaharan bahasa. Perilaku belajar tidak akan lepas dari dua komponen tersebut, dan oleh karena itu prestasi belajar yang dicapai pelajar tidak akan lepas darikemampuan verbal.

\section{PENUTUP}

Berdasarkan hasil analisis deskriptif dan pengujian hipotesis, maka ditarik simpulan sebagai berikut: (1) Tingkat kemampuan verbal siswa berada pada kategori sedang dengan nilai rata-rata 51,83; (2) Tingkat kemampuan menyelesaikan soal cerita siswa berada pada kategori sedang dengan nilai rata-rata 70,62 ; (3) Kemampuan verbal memiliki korelasi/hubungan dengan kemampuan menyelesaikan soal cerita matematika dengan besar hubungan 67,5\% dimana hal tersebut berada pada kategori sedang, selanjutnya hasil analisis deskriptif diperoleh bahwa terdapat 40 atau $27,59 \%$ siswa yang berada pada kategori tetap yaitu jika kemampuan verbal yang dimiliki berada pada suatu kategori, maka kemampuan menyelesaikan soal cerita yang dimiliki juga berada pada kategori yang sama dengan kemampuan verbalnya; 98 atau 67,59\% siswa yang berada pada kategori meningkat yaitu jika kemampuan verbal yang dimiliki berada pada suatu kategori tertentu, maka kemampuan menyelesaikan soal cerita yang dimilikinya akan lebih tinggi dari kemampuan verbalnya; dan 7 atau 4,83\% siswa yang berada pada kategori menurun artinya kemampuan menyelesaikan soal cerita yang dimilikinya akan lebih rendah dari kemapuan verbalnya; (3) Lebih lanjut kemampuan verbal berpengaruh positif terhadap kemampuan 
menyelesaikan soal cerita dengan pengaruh sebesar 42\% sedangkan sisanya sebesar 58\% dipengaruhi oleh variabel lain di luar model. Kemampuan verbal berpengaruh positif terhadap kemampuan menyelesaikan soal cerita siswa, hal tersebut dapat diartikan bahwa semakin baik atau semakin tinggi kemampuan verbal yang dimiliki oleh siswa maka kemampuan menyelesaikan soal cerita siswa tersebut akan semakin baik atau semakin tinggi. Penulis mengucapkan terima kasih kepada kedua orang tua, Istri dan anak-anakku tercinta yang selalu mendoakan dan memberikan motivasi penulis dalam melaksanakan penelitian sampai pada penyusunan artikel, serta kepala sekolah SMP Muhammadiyah Se-Kota Makassar yang telah memberikan izin untuk melaksanakan penelitian.

\section{DAFTAR PUSTAKA}

Burhanuddin, 2012. Pengaruh Strategi Pembelajaran Kooperatif dan Kemampuan Verbal terhadap Hasil Belajar Ips Siswa MTS Ulumul Qur'an Langsa. Jurnal Tabularasa, PPS Unimed.

Efendi, Kusno. 2004. Hubngan antara Konsep Diri dan Kemampuan Verbal dengan Prestasi Belajar pada Siswa SD Muhammadiyah Sukonandi Yogyakarta. Humanitas : Indonesian Psychologycal Journal Vol.1 No.1 Januari 2004:26-31.

Soeharno, 1984. Testologi Pengantar. Jakarta: Bina Aksara.

Wardhani, Sri. 2008. Paket Fasilitasi Pemberdayaan KKG/MGMP Matematika.

Wayan Nurkancana, 1983. Evaluasi Pendidikan, Surabaya. Usaha Nasional.

Wasito. 2010. "Pengaruh Kemampuan Penalaran, Kemampuan Verbal dan Kemampuan Numerik Terhadap Kemampuan Menyelesaikan Soal Cerita Matematika Pokok Bahasan Aritmetika Sosial (Studi Penelitian Pada Siswa Kelas VII Semester Genap SMP Negeri 3 Petarukan)" E-Jurnal UPS Tegal. 